\title{
Refeeding syndromeにたこつぼ型心筋症を合併したanorexia nervosaの1例
}

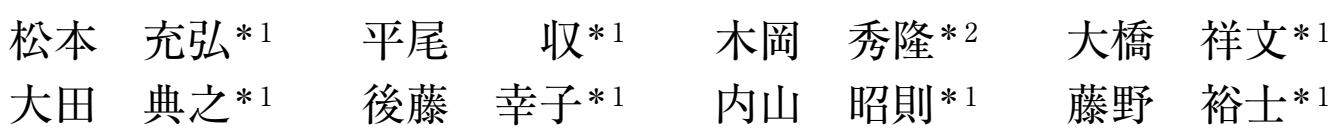

\begin{abstract}
要約：患者は 18 歳女性。神経性食思不振症 (anorexia nervosa, AN) のため, 当院精神科に入 院した。入院後，低血糖発作による意識レベルの低下を認めた。ブドウ糖液投与にて意識は 改善したが，心臟超音波検査 (ultrasonic echocardiogram, UCG) にてたこつぼ型心筋症の像を 認めた。また血液検査にて血清リン值が $0.9 \mathrm{mg} \cdot \mathrm{d} l^{-1}$ に低下していたため, refeeding syndrome と診断され, ICU入室となった。入室後, 血清リン值をはじめ適宜電解質の補正を しながら徐々に投与カロリーの増加を図った。電解質，体重の改善を認め，入室後 16 日目に ICU 退室となった。長期間低栄養状態にある患者に対して栄養投与をする場合，バイタルサ インや水分バランス，リンを含めた電解質異常を注意深く観察しながら治療すること，また 投与カロリーの増加を緩徐に行うことが重要である。
\end{abstract}

Key words: (1) refeeding syndrome, (2) takotsubo cardiomyopathy, (3)anorexia nervosa

\section{はじめに}

Refeeding syndromeは, 長期間にわたり栄養摂取 不良であった状態から急激な栄養摂取をすることによ り, 体液, 電解質が細胞外から細胞内一急激に移行す ることで陥る病態であり, 心血管・神経・血液系の合 併症を呈する。今回著者らは, refeeding syndromeに たこつほ型心筋症を合併した神経性食思不振症 (anorexia nervosa, AN)の1例を経験したので, 文献 的考察を含め報告する。

\section{症 例}

患者：18歳, 女性。身長 $163 \mathrm{~cm}$ 。

現病歴： 1 年前から大学受験勉強がストレスとな り, 食欲が減退し始めた〔当時体重 $55 \mathrm{~kg}$, 体格指数 (body mass index, BMI) 20.7〕6r月前より抑うつ 症状も出現し，近医精神科を受診し，抗うつ薬を処方 されるが症状改善せず，4ケ月前に当院精神科を受診

この論文は今号のハイライトで取り上げています。

石原 正治. たこつほ心筋障害. 日集中医誌 2010; 17: 133-135.
した (当時体重 $40 \mathrm{~kg}, \mathrm{BMI}$ 15)。その後も体重減少は 進行し，1 ケ月前には体重 $27 \mathrm{~kg}$, BMI 10.2 まで減少し た。その後, 水分摂取不良になり, 当院精神科に緊急 入院となった。

入院後経過: 入院当日の夕方, 低血糖 (血糖值 21 $\left.\mathrm{mg} \cdot \mathrm{d} l^{-1}\right)$ による意識レべル低下を認めたため, 当院 救命センターに入室した。ブドウ糖液投与によって 意識レベルは回復した。同日の頭部CTでは軽度の脳 萎縮を認めたものの, 他に頭蓋内病変は認めなかっ た。血液検查上は脱水, AST, ALT, $\gamma$ glutamyl transpeptidase ( $\gamma$ GTP)の上昇を認めた。

その後 2 日間, 中心静脈栄養, 経管栄養の両方で計 $768 \mathrm{kcal} \cdot \mathrm{day}^{-1}, 13.1 \mathrm{kcal} \cdot \mathrm{kg}^{-1} \cdot \mathrm{day}^{-1}$ の栄養を 投与した。

入院後 3 日目に尿量が減少したため, 心臟超音波検 查 (ultrasonic echocardiogram, UCG) を施行したとこ ろ, 左心室心尖部を中心とした領域の低収縮と心基部 の過剩収縮を認め, 左室駆出率 (ejection fraction, $\mathrm{EF}$ ) も20\%と著明に低下していた (Fig. 1a，b)。また患者 に胸痛などの既往はなかったが, 心電図 (electrocardiogram, ECG) では I, II, aVF, 抢よびV2〜V6 誘導 

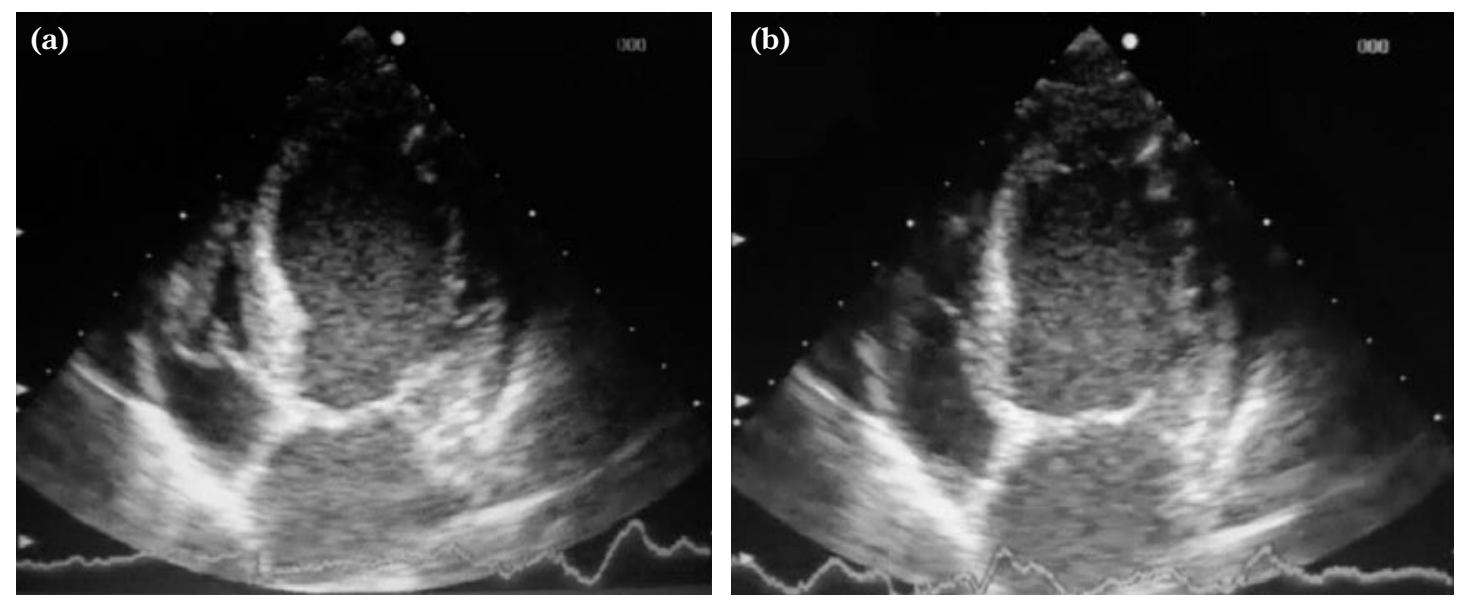

Fig. 1 Ultrasonic echocardiogram 3 days after admission to the hospital (a) Systolic phase, (b) Diastolic phase.

Poor contraction of the left ventricular apex was noted in the systolic phase.

でのST 上昇を認めた (Fig. 2a) ため, たこつぼ型心筋 症と診断した。

血液検查では血清リン值が $0.9 \mathrm{mg} \cdot \mathrm{d} l^{-1}$ に低下, また血清カリウム值も $3.3 \mathrm{mg} \cdot \mathrm{d} l^{-1}$ に低下していた。 栄養を十分に摂取できていなかった患者が低血糖発作 後に栄養再開したことにより, 血清リン・カリウム值 が低下し, 心機能が低下した。これら一連の経過より refeeding symdromeによる心機能低下を疑い, 栄養 投与量を減らし,リン酸ナトリウムの投与を開始した。

入院後 3 日目, 心機能, 電解質のモニタリングと栄 養コントロールを目的にICUに入室した。リン酸ナ トリウムは入室後も投与を続けた。入院後 5 日目には UCGにてEF 30\%と, 心機能の軽度改善を認めた。し かし, 心囊液眝留と, 胸部 X線写真上で左胸水がみら れた。水分投与が過剩であったと判断し，フロセミド の投与を開始した。しかし, 入院後7日目には胸水が 両肺野に出現し改善傾向はみられず，入院後10日目 に右胸垫ドレナージを施行した。しかし，その後も呼 吸状態の改善がみられなかったため気管抻管し, 人工 呼吸管理となった。翌日には呼吸状態が改善したので 抜管した。入院後 12 日目に心機能の改善を認め(Fig. 3a，b)，心囊液は認められなくなり，左室壁運動もほ ぼ正常化していた。た ECG上ではST上昇が消失し，

I，II，aVF，抢よび $\mathrm{V} 3 〜 \mathrm{~V} 6$ 誘導に陰性 T波を認めた (Fig. 2b)。全身状態が改善したため, 入院後18日目 に当院精神科病棟へ転棟した。

\section{考 察}

Refeeding syndromeは, 第2次世界大戦後の日本の 捕虜の人々に発症したとして最初に報告された1)。
2〜3ケ月のうちに体重が $10 \%$ 以上の減少を認めてい たり, 過度のストレスやうつ状態から 7〜10日以上食 物を摂取できない状態が続く人々に起こり得る2)。 Refeeding syndromeは, 長期間にわたり栄養摂取不 良であった状態から急激な栄養摂取をすることによ り, 体液, 電解質 (特にリン) が細胞外から細胞内へ急 激に移行することで陥る病態であり, 通常は栄養摂取 再開後4 日以内に発症する。エネルギー基質の外から の供給が不十分な状態では, 体脂肪を分解して遊離脂 肪酸とケトン体をエネルギー源とする代謝経路に生体 が適応している。そこに糖質が急激に入ることにより， 膵臟のインスリン分泌が刺激される。その結果, 細胞 内にグルコース, リン, カリウムやマグネシウム, 水 が取り込まれ, 低リン血症, 低カリウム血症, 低マグ ネシウム血症, 脱水となり, refeeding syndromeを引 き起こすのである2)。低リン血症は心収縮力の低下, 低カリウム血症は不整脈や心停止, 低マグネシウム血 症は torsades de pointesなどの不整脈をそれぞれ引き 起こす2)。また稀ではあるが, 肝不全に陥ったとの報 告もある31。

Refeeding syndromeは発症早期の臨床症状が非特 異的であり，それゆえ認識されにくい。したがって， refeeding syndromeを予防するためには, まず発症の 可能性のある患者に対して refeeding syndromeが起 こり得ることを医療従事者が認識し, バイタルサイン や水分バランス, 電解質異常を注意深く観察すること が重要である。特に血清リン值は適宜測定し, 適切な 量のリンを経口ではなく, 経静脈的に投与するべきで ある ${ }^{4)}$ 。具体的には, 腎機能が正常な低リン血症の患 者の場合, $50 \mathrm{mmol}$ のリンを経静脈的に 24 時間かけ 
(a)

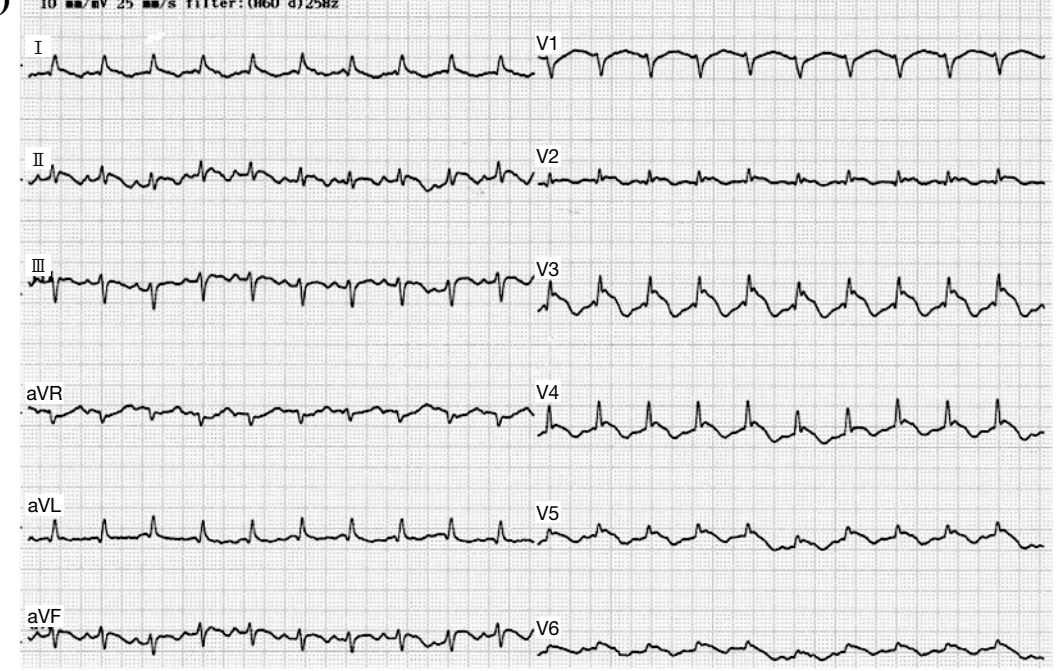

(b)

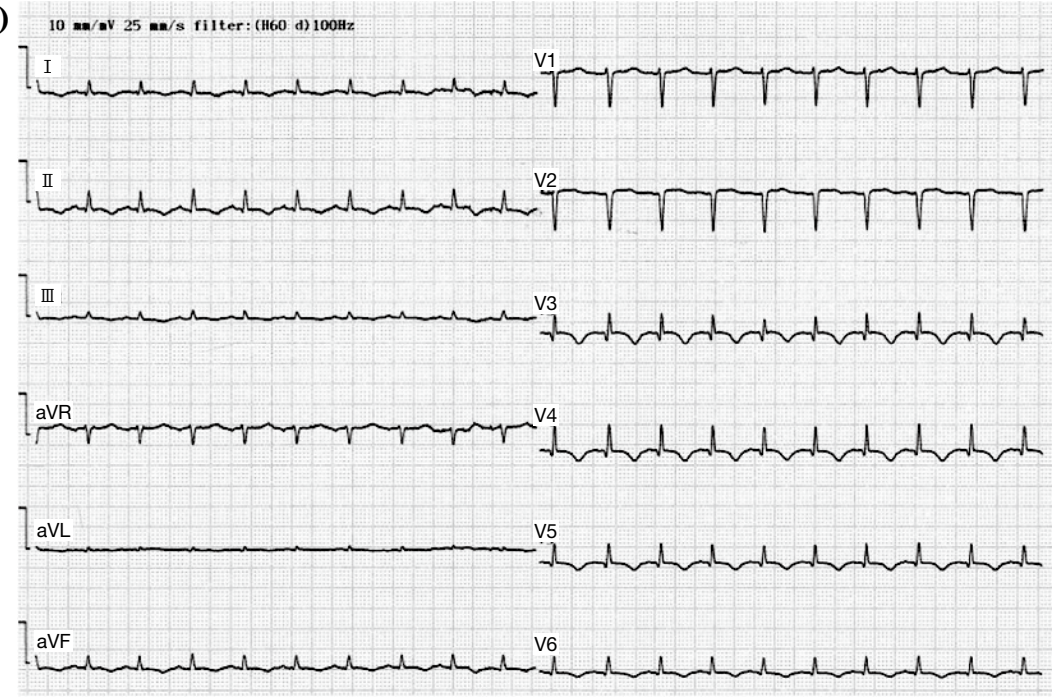

Fig. 2 Electrocardiogram

(a) Three days after admission to the hospital. It revealed sinus tachycardia with ST elevation in leads I, II, aVF, and V2 V6.

(b) Twelve days after admission to the hospital. No ST elevation was noted, and development of diffuse, and often deep, T-wave inversion was noted in leads I, II, aVF, and $\mathrm{V} 3 \sim \mathrm{V} 6$.
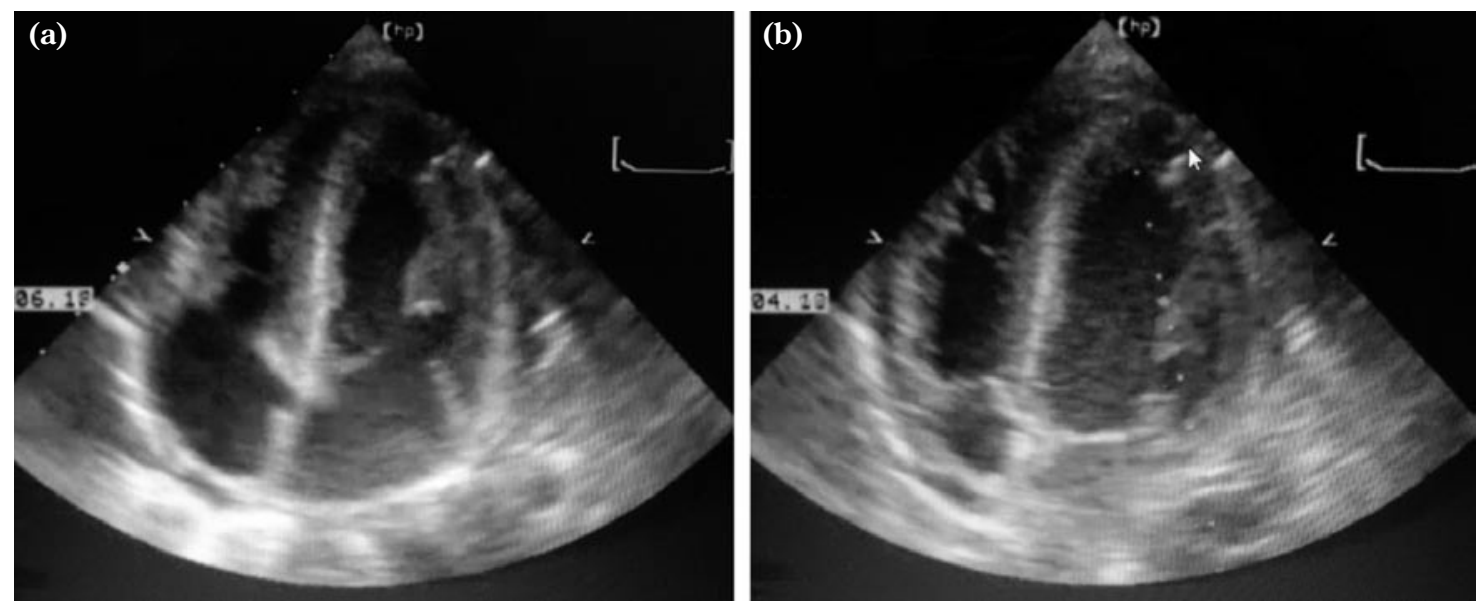

Fig. 3 Ultrasonic echocardiogram 12 days after admission to the hospital (a) Systolic phase, (b) Diastolic phase.

Normal contraction of the left ventricle is observed. 
て投与することが推奨されている4)。また経腸栄養な ど, 非経口栄養を開始する時には, 必要とされるカロ リーの 25〜 50\%程度から開始すべきである。そして 栄養開始前の血清リン值, カリウム値, マグネシウム 值, カルシウム値, 尿素窒素值, クレアチニン值を測 定しておき, 栄養開始後 4 日間は毎日電解質の検査を 施行して適宜補正を行うべきである4)。またSolanto らは, 栄養開始後 4 日間は体重増加を $0.36 \sim 0.55 \mathrm{~kg}$ に 留めるべきとしている5)。Nutrition support team (NST) による栄養指導や食事管理も非常に重要であ る2)。今回著者らが経験した症例では，当院栄養管理 部に相談し, 理想体重 (ideal body weight, IBW) をも とに栄養投与開始を $13.1 \mathrm{kcal} \cdot \mathrm{kg}^{-1} \cdot \mathrm{day}^{-1}$ とした が，これではrefeeding syndromeを起こす可能性が あり,やはり現体重をもとに栄養投与を調整したほう がよいと考える。

今回著者らが経験した症例は, ICU入室前にUCG にてたこつぼ型心筋症の像を認め, EFも20\%まで低 下していた。たこつぼ型心筋症は1990年に佐藤らが 最初に報告したものであり ${ }^{6}$ ), 疾患名は左心室の形状 がたこつぼに似ていることに由来する。感情的ストレ ス, くも膜下出血, 外傷, 褐色細胞腫, カテコラミン投 与などを契機として発症する。感情的ストレスなどで カテコラミンレベルが上昇することにより左室心尖部 の心筋のカテコラミンレセプターが活性化し, 左室心 尖部の機能を低下させることが実験的に証明されてい るものの7), たこつぼ型心筋症の原因が心筋細胞が直 接傷害されることによるものなのか, あるいは冠動脈 の攣縮による虚血，また微小血管の攣縮によるもので あるのか, その機序はよくわかっていない8)。たこっ ほ型心筋症の診断基準は, 以下の5つである。

(1)急性心筋梗塞に類似した発症経過である。

(2)急性期に左室造影検査やUCGにて, 左心室心尖 部を中心とした領域の低収縮と心基部の過収縮 を呈する。

(3)その収縮異常は 2 週間以内に劇的に改善する。

(4)心収縮異常域は一枝の支配領域を越えている。

(5)責任病変と妥当な冠動脈に器質的病変を示さな い。

診断基準(3に示すように, 今回著者らが経験した症 例も発症後10日目にUCG上でたこつほ型心筋症の像 は認められなくなり，またEFもほほ正常化した。 たこつぼ型心筋症はECGにて50〜 60\%にST上昇が 認められ，また，その後 ST上昇の消失とともにほと んどの誘導にて陰性 T波を認めるのが特徴的である が9), 今回著者らが経験した症例でも I, II, aVF，お
よび $\mathrm{V} 2 \sim \mathrm{V} 6$ 誘導での $\mathrm{ST}$ 上昇を認め, その後 $\mathrm{ST}$ 上昇 の消失とともに I, II, a VF，およびV3〜V6誘導に陰 性T波を認めた。2005年, Ohwadaらは, ANの患者 が低血糖発作後にたこつぼ型心筋症を発症した症例を 報告している10)。彼らによると, 低血糖発作を起こ した患者に対し,ブドウ糖投与にて状態が改善したが, その翌日にUCGにてたこつほ型心筋症を認めている。 この報告では血清リン值については触れられていない が, 著者らが経験した症例のように, 低リン血症が関 与していた可能性がある。また, たこつぼ型心筋症の 像を呈する期間は比較的短いため, refeeding syndromeを発症する可能性がある患者に対しては, 比較的早期から UCGを施行することが重要であると 考える。

2001年, Frolickらは, ANの患者 65 人のうち 10 人 に心囊液貯留を認めたと報告している11)。彼らによ ると, 患者の体重増加とともに心囊液貯留が改善した ため, 心囊液貯留は体重の増加, 改善と相関関倸があ り得るとしている。本症例でもUCGにて心囊液䝪留 を認めたが, 心不全症状を呈することなく患者の体重 増加とともに改善した。また本症例では入院後7日目 に胸水の貯留を認め, 胸腔ドレナージや人工呼吸管理 が必要となった。このことから, 栄養管理とともに水 分管理が重要であると考えられた。

\section{結 語}

Refeeding syndromeにたこつぼ型心筋症を合併し た ANの 1 例を経験した。長期間にわたり栄養摂取不 良であった患者に対して栄養投与をする場合, refeeding syndromeが起こり得るということを十分 に認識し,バイタルサインや水分バランス,リンを含 めた電解質異常を注意深く観察しながら治療するこ と, また投与カロリーの増加を緩徐に行うことが重要 である。

本稿の要旨は, 第 52 回日本集中治療医学会近畿地方会 (2007年, 大阪)にて発表した。

\section{文 献}

1) Schnitker MA, Mattman PE, Bliss TL. A clinical study of malnutrition in Japanese prisoners of war. Ann Intern Med. 1951;35:69-96.

2) Crook MA, Hally V, Panteli JV. The importance of the refeeding syndrome. Nutrition. 2001;17:632-7.

3) Azumagawa K, Kambara Y, Kawamura N, et al. Anorexia nervosa and refeeding syndrome. A case report. ScientificWorldJournal. 2007;7:400-3.

4) Hearing SD. Refeeding syndrome. BMJ. 2004;328:908-9. 
5) Solanto MV, Jacobson MS, Heller L, et al. Rate of weight gain of inpatients with anorexia nervosa under two behavioral contracts. Pediatrics. 1994;93:989.

6) 佐藤 光, 立石博信, 内田俊明, 他. 多枝 spasmにより特 異的な左室造影像「ツボ型」を示したstunned myocardium. 児玉和久, 土師一夫, 堀 正二編. 臨床からみた心筋細胞 障害 一虚血から心不全まで. 東京：科学評論社；1990. p. 56-64.

7) Mori H, Ishikawa S, Kojima S, et al. Increased responsiveness of left ventricular apical myocardium to adrenergic stimuli. Cardiovasc Res. 1993;27:192-8.

8) Wittstein IS, Thiemann DR, Lima JAC, et al. Neuro- humoral features of myocardial stunning due to sudden emotional stress. N Engl J Med. 2005;352:539-48.

9) Prasad A. Apical ballooning syndrome; an important differential diagnosis of acute myocardialinfarction. Circulation. 2007;115:e56-9.

10) Ohwada R, Hotta M, Kimura H, et al. Ampulla Cardiomyopathy after hypoglycemia in three young female patients with anorexia nervosa. Intem Med. 2005;44:228-33.

11) Frolick J, von Gontard A, Lehmkuhl G, et al. Pericardial effusions in anorexia nervosa. Eur Child Adolesc Psychiatry. 2001;10:54-7.

\title{
Abstract \\ A case of anorexia nervosa complicated with refeeding syndrome and takotsubo cardiomyopathy
}

\author{
Atsuhiro Matsumoto*1, Osamu Hirao*1, Hidetaka Kioka*2, Yoshifumi Ohashi*1, Noriyuki Ohta*1, \\ Yukiko Goto*1, Akinori Uchiyama*1, Yuji Fujino*1 \\ ${ }^{* 1}$ Department of Intensive Care Unit, ${ }^{* 2}$ Department of Cardiovascular Medicine, Osaka University Hospital \\ 2-15 Yamadaoka, Suita, Osaka 565-0871, Japan
}

This is a report of the case of an 18 year-old woman who was admitted to a psychiatric hospital for anorexia nervosa. After admission, hypoglycemic coma developed as a complication, and although she recovered from the coma in response to intravenous glucose administration, an ultrasonic echocardiogram (UCG) demonstrated takotsubo cardiomyopathy. Because the patient's serum phosphate level had decreased to $0.9 \mathrm{mg} \cdot \mathrm{d} l^{-1}$, she was diagnosed with refeeding syndrome and admitted to the ICU. Artificial feeding (both enteral and parenteral), early supplementation with phosphorous, and other electrolytes were started at a reduced calorific rate. The patient recovered, and she was discharged to a general ward on ICU day 16. When nutrition is started after prolonged starvation, it is important to start at a reduced calorific rate and to monitor vital signs, electrolyte levels, and water balance closely in order to prevent refeeding syndrome.

Key words: (1) refeeding syndrome, (2) takotsubo cardiomyopathy, (3) anorexia nervosa

J Jpn Soc Intensive Care Med. 2010;17:185 189. 